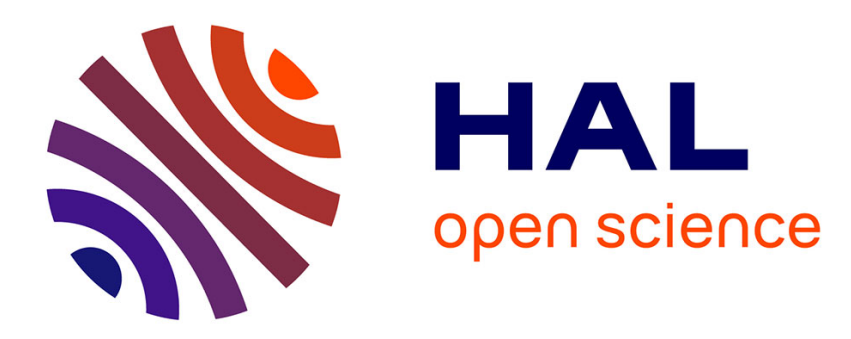

\title{
Computers and Excellence in the Future of Education
}

Roy D. Pea

\section{To cite this version:}

Roy D. Pea. Computers and Excellence in the Future of Education. Annals of the New York Academy of Sciences, 1988, 517, pp.125-138. hal-00190552

\section{HAL Id: hal-00190552 https://telearn.archives-ouvertes.fr/hal-00190552}

Submitted on 23 Nov 2007

HAL is a multi-disciplinary open access archive for the deposit and dissemination of scientific research documents, whether they are published or not. The documents may come from teaching and research institutions in France or abroad, or from public or private research centers.
L'archive ouverte pluridisciplinaire HAL, est destinée au dépôt et à la diffusion de documents scientifiques de niveau recherche, publiés ou non, émanant des établissements d'enseignement et de recherche français ou étrangers, des laboratoires publics ou privés. 


\title{
Computers and Excellence in the Future of Education
}

\author{
ROY D. PE.t \\ Luboratory for tovonced Research in \\ Edurationat Technologies \\ vew York Lawersir. \\ School of Educarion \\ ven York. vew York 10003
}

ANNALS OF THE NEW YORK ACADEMY OF SCIENCES

Volume 517

\section{PSYCHOLOGY AND EDUCATIONAL POLICY}

Edited by Jeri A. Sechzer and Sheila M. Pfatflin

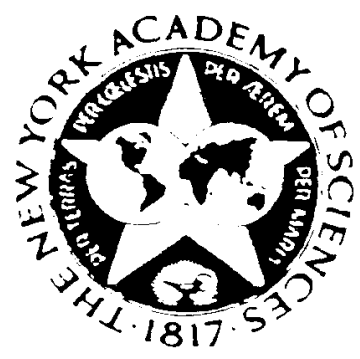


Volume 517

December 31, 1987

PSYCHOLOGY AND EDUCATIONAL POLICYa

\section{Editors}

Jeri A. Sechzer and Sheila M. Pfafflin

\section{CONTENTS}

Dedication

Introductory Remarks. By JERI A. Sechzer

\section{Part I. A Nation at Risk: Relevant Issues}

Introduction: Psychological Perspectives on Educational Policy. By JefFerson M. Fish . . . . . . . . . . . . . . . . . . . . . . . . . .

A Nation at Risk: Towards Excellence for All. By Tommy M. Tomlinson ... 5

Demography, Demagoguery, and Test Performance. By Thomas L. Hilton

Cognitive Research Relevant to Education. $B y$ Michelene T. H. Chi and James

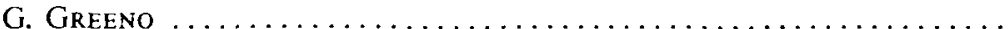

\section{Part II. Issues of Gender in the Educational Process}

Introduction. $B y$ Jeri A. Sechzer and Sheila M. Pfafflin . . . . . . . . .

Research Context of Studies for Sex Differences in Mathematics Performance.

By Florence L. Denmark and Frances Francols .............

Biological Correlates of Spatial Ability and Mathematical Performance. By ANNE

C. Perersen and Lisa J. Crocketr .....................

Issues in the Construction and Use of Tests in Studies of Sex Differences in

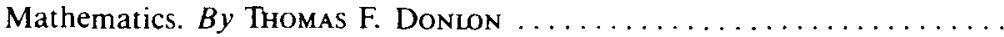

Sex Differences among the Mathematically Gifted. By LyNN H. Fox

\section{Part III. Education for the Future}

Educational Technology and the Future of Education. By Sheila M. Pfaffin

Some Perspectives on the New "Crisis" in American Education. By MarTin

DEUTSCH

a This volume is the result of a meeting entitled Psychology and Educational Policy held in New York City on October 15, 1983 by the Section of Psychology of the New York Academy of Sciences. 
Computers and Excellence in the Future of Education. $B y$ RoY D. PEA ...

The Classroom of the Future. By Leonard Krasner and Miriam Krasner 139

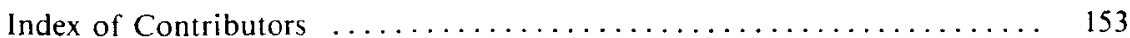

The New York Academy of Sciences believes that it has a responsibility to provide an open forum for discussion of scientific questions. The positions taken by the participants in the reported conferences are their own and not necessarily those of the Academy. The Academy has no intent to influence legislation by providing such forums. 


\title{
Computers and Excellence in the Future of Education
}

\author{
ROY D. PEA \\ Laboratory for Advanced Research in \\ Educational Technologies \\ New York University \\ School of Education \\ New York, New York 10003
}

\section{INTRODLCTION}

The report of the National Commission on Excellence in Education (NCEE) calls for a "Learning Society" that "affords all members the opportunity to stretch their minds to full capacity, from early childhood through adulthood, learning more as the world itself changes." My goal in this essay is to highlight some of the central roles that computer technologies could serve in supporting the major reforms needed to create this society.

The themes I aim to articulate chart a course between technologies available or under development today, and what is likely to be feasible or achievable in the decade ahead as we rebuild our systems of learning. One often hears outlined a dreamland of education served by technologies, but naive to the ideological, political, and economic constraints that have an impact on any educational innovation. Instead we should ask: Where can we look for hopes, for direction, and for the agents of change that will unlock the educational potentialities of computer technologies for enhancing learning processes throughout life? One can focus too much attention on such issues as the restrictions and problems being experienced with computers in schools today, or the unrealistic tomorrows in which computers have supplanted classrooms and teachers, or the fact that the complexities of successful human teaching interactions are assumed programmable. We need plausible projections that will guide educational planning, and provide justifiable hopes for the new technologies. These times demand principled analysis, critical reflection, and practical plans rather than wishful thinking about fantastic roles for computers in education. In search of a panacea, we cannot be blinded to what we know about how people learn, how teachers teach, and the political and economic edifice upon which our education depends. At the same time, one cannot deny that computer tools could reseam the fabrics of learning. But the "technoromanticism" we hold to should be one tempered by critical and realistic attitudes. 


\section{Outline of Approach}

Less than a year ago. the Department of Education (DOE) held an ex citing conference on the future of computers in education and the research needed to realize their potential (Lesgold and Reif. 1983). Representing edu cation. computer science, psychology. software and hardware companies, and other diverse disciplines. the conferees found substantial agreement in their recommendations for future directions to take with the development and use of computer technologies. At the same time, the magnitude of problems in education has been recognized and publicized through the reports of the Commission and many other national studies (Griesemer and Butler. 1983). At this intersection of concerns, what can be done?

My plan in this essay is first to review the four basic problems which the Commission for Excellence in Education has identified in our educational process. and its recommendations for solving them. Since, unfortunately, the Commission's recommendations are largely silent on the central roles that will be played by new technologies together with psychological research in achieving this excellence, my task will be to highlight them by setting the recommendations of the DOE report (Lesgold and Reif, 1983) and other suggestions of fered by educational technologies, alongside the problems earmarked by the Commission.

\section{Questions about Learning, Knowing, and Equity}

I know I am not alone in wondering how the learning necessary for achieving the new and rigorous educational standards and expectations the Commission recommends will be accomplished. Defining "Neu Basics," including computer science, and pointing to their rigor alone will be unlikely to lead to excellence in educational achievement or practice. We need basic improvements in the processes of education, and in its responsiveness to the new skill requirements of an information age. After centuries we are only now encountering explicit accounts of the way in which people learn, of the nurturing of the romance for learning we all possess, and of the wider propagation of expertise. Yet students continue to turn off, overburdened by what Whitehead called the "inert facts" they are taught and by disconnected subjects which are remote from and devoid of life and meaning.

At the same time, there is widespread recognition that the very definition of "knowledge" is changing. In the past. even given its shortcomings, it was often enough to get through school that a student had merely to memorize facts. But with the advent of the information revolution, our basic understanding of "knowing" has come to be reworked. No epistemologist is likely to be satisfied with either emphasis on what knowing is, but for the nonphilosophical educator and information consumer, it is a fundamental shift of emphasis all the same (Simon, 1981). To "know" today is less to hold a storehouse of ideas in the mind than to be able to find and use information effectively. Today "knowing" is information management, rather than infor- 
mation possession. Knowing in this sense is more integrally linked to doings, such as formulating questions, testing hypotheses, writing reports, solving problems, getting work accomplished, and deciding as to what one should do in the world. This is the most important kind of "transfer" of school learning we can hope for.

On the heels of this new sense of the "knowing" that is a fundamental aim of education, we need intensive national efforts on basic and applied research that uses and modifies educational technologies in schools in order to build upon recent insights into learning processes and human intelligence (e.g., Davis, 1982; Gagne and Dick, 1983; Glaser, 1984; Resnick, 1982; Sternberg, 1982). We have to learn not only how to teach students how to learn, to think critically, and to manage information, but also how to keep a child's native curiosity alive, as well as to develop what Kenneth Burke calls our inherent "spirit of perfection." The new skills of knowing must grow in both formal and informal learning environments for students of all socioeconomic levels. This is the Jeffersonian ideal, and it has become newly endangered by inadequate access to computers for female, minority, and rural students (Anderson, Welch and Harris, 1983; Sheingold, Kane and Endreweit, 1983). Massive national efforts will be required to insure equity of quality access to these learning and teaching technologies, and massive research and development efforts are needed to create the best computer-enhanced learning environments. Only with these twin achievements can the rich potentialities of the new technologies be relied upon as tools to serve universal learning.

\section{The New Information Technologies}

What are the new information technologies? Many remember the first excitement about computers and "automatic teaching machines" in the late 1950s and the 1960s (Lumsdaine and Glaser, 1960). There are very few points in common between this earlier movement and today's technologies (see TABLE 1). Though many still view the computer as a machine for crunching numbers, its greatest powers for education lie in its capacities for storing, organizing, and manipulating symbols (Newell and Simon, 1972, 1976). The symbolic power of the computer is remarkable, and in extreme cases, as with the discovery of techniques for mass spectrometry of molecular structures in chemistry by the Meta-DENDRAL program (Buchanan et al., 1976), computers have rivalled

TABLE 1. The New Technologies for Education

- Widely accessible microcomputers and software

- Interactive videodisc systems

- High-quality computer graphics tools

- Rich intermedia learning environments

- Networking of microcomputers

- Pointing devices for interacting with computer

- Computer speech understanding and production

- "Intelligent" coaching and tutoring systems 
human abilities as to the extent of their creativity and importance (Barr and Feigenbaum, 1982).

But there is a contrast to be drawn here. Most educators and parents have probably seen only simplistic canned computer-aided drill and practice programs, and wondered how might they ever be able to ignite the imagination of young learners. But today, very rich problem-solving tools and intelligence stimulations useful for hypothesis-testing, discovery learning, and "learning by doing" are becoming more widely available - across the traditional curriculum and beyond it, as the educational requirements and tools of an information age change with regard to students' need to know and how they may learn it.

For example, interactive computer systems are being created that allow people to choose from millions of images on videodiscs in order to accomplish learning with the aid of an automated encyclopedia complete with images, text, and, eventually, sound. Soon to be available to schools are the incredible computer graphics, editing, and production tools used by designers, architects, artists and musicians. The use of such tools has revolutionized television and movie graphics and sound. Educational projects which create rich learning environments by integrating learning activities with the media of television, print materials, laboratories, and computer software are also under way (Char et al., 1983). Students are already using networked systems of computers, enjoying new opportunities to link their enthusiasm for communication with practice of literacy activities like critical reading and writing. They now can create and use their own messages, programs, and text for writing newspaper articles which have been created on a computer and then sent within schools or between states (Riel, 1983). Across such networks, special interest groups of children or adults will meet and, perhaps less attentive to age differences, form intellectual communities and work together on shared activities and in learning collectives (Brown, 1983a, 1983b).

The development of new input devices is also allowing young children who do not yet know how to read - to interact with learning software and construct novel learning episodes and new forms of play by pointing at iconic symbols on the screen, by drawing on graphics tablets, and by selecting what to do from the computer's displayed menu of options by either aiming a light pen at the screen, touching the screen, or rolling a mechanical mouse to position a cursor on the screen and then pushing a button (Warfield and White, 1983; Xerox Palo Alto Research Center, 1983).

Much progress is also being made in machine speech understanding, a fact which could revolutionize the practice of acquiring literacy. There are talking electronic books and interactive reading programs that say aloud what children have entered at the keyboard. As students read text on a screen, they can touch words they do not know and hear them spoken (Rosegrant, 1983). And the first interactive book with electronic topic browsing capabilities has been created at Xerox Palo Alto Research Center (Weyer, 1982).

Perhaps most important, work on "artificially intelligent" computer systems that can understand situations and model the mental activities of human problem solvers is being implemented in "intelligent" reactive coaching and tutoring systems (Barr and Feigenbaum, 1982; Sleeman and Brown, 1982). 
These systems will deal with specific subject areas and diagnose a student's misconceptions, give appropriate advice, and offer a staircase of knowledgeappropriate learning experiences that build toward expertise. The understanding of algebra, geometry, and physics is a major emphasis of current research. Many of these new developments are dependent on psychological research (especially in cognitive science) which has provided new and promising insights concerning the processes by which learning and teaching take place (Gagne and Dick, 1983; Resnick, 1982). Other major advances have been made through studies of human factors, and in the new field of cognitive engineering (Norman, 1980), which aims to design interfaces between humans and machines that are "cognitively transparent" and thus present minimal obstacles to the effective use of the computer as a problem-solving tool. Monumental efforts will now be required for research and development regarding school practices in order to foster the establishment and refinement of prototypes of computeraided learning environments for the future. Complex issues are raised for classroom organization (Amarel, 1983; Hawkins, 1983; Sheingold, Hawkins and Char, 1984) and for relations between formal and informal learning (Perkins, 1983).

\section{OUTLINE OF NCEE RECOMMENDATIONS}

As is well-known, the Commission identified four major groups of problems to do with educational processes: (1) problems with content, particularly concerning the existence of a curricular smorgasbord and large percentage of "general track" courses, which are too diluted and diffuse; (2) problems with too undemanding expectations concerning student knowledge and abilities; (3) problems with time, too ineffectively used and inadequate for academic study; and (4) problems with teachers, who are too few in number, too undertrained, unqualified, and poor in college achievement. I will briefly review the Commission's recommendations for each problem area, and then offer prominent examples of the functions technologies and instructional psychology can be expected to serve in helping solve them. Each area is fraught with the inherent complexities of issues of educational practice and theory, and will not admit of easy solutions. All will require a national dialogue among informed educators and citizens about the challenges and priorities of an information age.

\section{Problem Area 1: Content}

Regarding content, the Commission recommends required knowledge of the "Five New Basics" (English, mathematics, science, social studies, computer science), and a strengthening of graduation requirements. They quite appropriately emphasize that this knowledge will serve as the "foundation of success for the after-school years," i.e., for life-long learning. To this end, members of the Learning Society will have to learn to apply their knowledge, or as Whitehead more appropriately called it, "wisdom," to the problems of everyday life. 


\section{Problems with Content: Roles for Technologies}

Four major roles for technology in supporting the learning of the Five New Basics and their associated cognitive skills will be in: (1) providing meaningful and stimulating learning that is linked to problems of everyday life; (2) creating, through research and development prototypes of computerenhanced learning environments for embodying and adapting instructional theories; (3) promoting more effective thinking skills; and (4) establishing an easily accessible, computer-based, national resource library of learning materials, from electronic books to software and videodisc.

\section{Providing Functional Learning Environments}

There is no question that today's education suffers for being too far removed from the problem-solving and thinking of everyday life. In mathematics and science particularly, this is a problem of epidemic proportions, and has been widely lamented in the educational community (e.g., Champagne and Klopfer, 1977; Daedulus, 1983; White, 1981). How can technologies be used to bridge these important gaps, to give meaning to school learning?

I believe this problem is one and the same as maintaining a student's essential enthusiasm for learning. If learning activities are for a purpose that a pupil can assimilate as his or her own, then learning is more likely to be achieved. Information technologies can help us save from extinction, or help rekindle, this fiery spirit and love for learning. But this is, of course, not just an individual task, but a deeply social one, since nationwide or peer group attitudes influence individuals' goals through displays of their messages as to what part of learning is or is not significant and worthy of personal commitment.

At first glance, it might appear that the thing to do is to forge connections between academic learning and the potent passions of videogame play (Loftus and Loftus, 1983). This approach has been exploited already with success in the educational training efforts of the military. But this direction appears risky in its overreliance on extrinsic motivation, since the features of the game medium overwhelm the prominence of what is learned.

In contrast, one major avenue for making learning activities with computers meaningful can be created today. We should be providing children in school-learning environments with access to the same powerful computer "thinking tools" that adults use as aides to solve everyday problems. No one questions the utility of text editors; systems for creating, retrieving, and organizing information from large databases; electronic spreadsheets like Visicalc; and electronic mail and publishing systems in the everyday adult world. And these tools are finally beginning to be used in innovative ways in schools (Bruce et al., 1984; Freèman, Hawkins and Char, 1984; Kelman et al., 1983; Levin et al., 1983; Pea and Kurland, 1984). Unlike factual learning about computers in "computer literacy" courses, acquiring skills with such tools has immediate 
relevance to activities in the world outside of school, and later in the students' lives.

On another realistic level, simulations of complex and intriguing systems such as ecosystems or power plants, can be used to help students build an understanding of relationships between variables and to expand traditional laboratories by developing a pupil's processes of mental inquiry. For example, STEAMER is a state-of-the-art knowledge-based computer training program for propulsion engineering developed by Bolt Beranek and Newman in Cambridge (Stevens et al., 1981; Williams et al., 1981). STEAMER is an excellent example of meaningful learning, since students can access tutorials on basic physics principles which are explained in the context of an operating model of a propulsion steamplant they are seeking to understand.

\section{Creating Prototype Computer Learning Environments for Embodying and Adapting Instructional Theories}

Instructional theories that are very specific about how students acquire understanding of such specific domains of knowledge as the Newtonian laws of motion (DiSessa, 1982) can lead to hypotheses about optimal sequences or paths between learning activities which can be tested and refined in classrooms by means of replicable computer-enhanced learning interactions. One major insight in recent studies on learning has been the prevalence of SAFs or "student alternative frameworks" for complex concepts such as motion, force, and velocity, which students bring to the classroom, formed by intui- tion and everyday experiences. Much current work in cognitive science has been addressed to the means of overcoming these potent misconceptions (e.g., Gentner and Stevens, 1983).

\section{Promoting Higher Thinking and Problem-Solving Skills}

Virtually all the major reports on education set as a major goal the learning of higher-order thinking skills, from strategic study skills such as planning and checking and summarizing, to critical reasoning, which involves imagining and synthesizing. The shortcomings of an education whose knowledge is not put to work throughout life by these critical "executive" abilities are clear. New cognitive research is systematically investigating how to best teach such thinking skills directly (Chipman, Siegel and Glaser, 1984; Siegel, Chipman and Glaser, 1984), and very creative efforts are under way to design computer-learning environments that will prompt these activities during student use, and provide examples of them in use for the domain being learned. Computer environments for supporting the development of these metacognitive skills in reading and writing are already appearing (Bruce et al., 1984; Pea and Kurland, 1984). We may expect that major advances will be made on this front within the next decade. 


\section{Electronic Sources for Learning Materials}

Finally, the well-known difficulties of maintaining up-to-date learning resources for schools may become more soluble with computer technologies. New technologies provide radically new alternatives for high-quality resources accessible to schools throughout the country. With Federal initiative, an easily expandable national curricular resources center could be established. Highquality software and other learning materials and activities could be regularly "downloaded" over computer networks to the nation's schools and homes, and regularly updated as the knowledge base and skills of society expand and change.

\section{Problem Area 2: Standards and Expectations}

To solve the problems regarding excessively low standards and expectations, the Commission recommends more rigorous content and measurable standards of achievement, higher expectations on the part of educators for what students can achieve, and the raising of university admission requirements. They greatly rely on and recommend even greater use of current standardized tests of achievement as benchmarks of progress toward excellence.

\section{Problems with Standards and Expectations: Roles for Technologies}

Although necessary for greater excellence in education, higher goal-setting alone will not repair the weak fabric of learning in our schools. We must also have better means for the attainment of these goals. Technology can serve us in many ways. Computers will be used: (1) to do research in classrooms, as mentioned previously, on how to help all students learn and think critically about the substantive content of the Five New Basics and other aspects of the curriculum; (2) to develop and test new cognitive assessment tools for measuring student learning progress; (3) to "network" with educators so that they can call attention to specific problems in teaching and learning, or to details of innovative programs on "electronic bulletin boards" or conferencing systems, and receive quick responses from other members of the educational community throughout the country; and (4) to allow for interactive videodisc displays of master teachers in action for specific subject areas, configurations of learning resources, and levels of student ability. These are grand agendas. But they will soon be possible, since the power of 1983's supercomputers will cost less than $\$ 100$ by the early 1990s. And they are certainly warranted, since our nation's future hangs in the balance of our successes or failures in education.

New Cognitive Assessment Tools

Inadequacies in current tests for guiding educational interventions and di- 
agnosing learning problems have led to fundamental changes in our definitions of intelligence in the last several years (Sternberg, 1982; Tyler and White, 1979). The next generation of measurement instruments and achievement tests, emerging from the field of "cognitive psychometrics," will provide new benchmarks of progress toward excellence. In computer-interactive testing environments, they will identify specific patterns of deficiencies revealed by a student's misunderstanding of specific subject areas and problem types. More attuned to the specific kinds of knowledge and skills an expert develops in each domain of competency, these systems will diagnose the types of misunderstandings children have in ways immediately relevant for helping the teacher decide what instructional activities need to follow. Too much teaching today is teaching for successful performance on achievement tests, rather than for usable knowledge and problem-solving skills. For students from exceptional populations, these new knowledge-diagnosis tools and their complementary learning environments appear especially promising.

\section{Computer Networks and Conferencing}

Movements are also afoot, very actively in New York among other states, to build extensive networks linking educators and educational policymakers to each other and to educational resources, such as from libraries to museums. One activity already gaining momentum is the use of problem-solving "electronic bulletin boards" by educators, and others include computer-based conferences on textbooks, software, curriculum issues, and problems of teaching and learning.

\section{New Technologies as Resources for Cognitive Process Instruction}

"Cognitive modelling" is another teaching activity that may come to greatly benefit learning. The central idea is that the processes of problem-solving and the use of higher mental skills may be elusive to students, and could be conveyed by example, and repeatedly observed from some recorded device. The computer is able to represent and communicate the steps of a problem-solving process, say in working an algebra problem. Since learning by example is such an important activity in apprenticeships of various kinds, cognitive science has begun to evaluate the feasibility of using such computer traces, films, or videodiscs of problem-solvers as they think aloud while working on problems, such as writing an essay, or describing the kinds of decisions, strategies, and information they are utilizing in their mental work. New technologies could guide the design, choice, and dissemination of such resources. For example, J. S. Brown (1982) of Xerox Palo Alto Research Center has been creating computer learning tools that "mirror" a student's thought processes back to them as they solve a problem, with the aim of helping the student reflect on those processes and develop important metacognitive skills. 


\section{Problem Area 3: Time}

As for problems of educational time-management and availability, the Commission recommends that more school time be devoted to learning the New Basics. To accomplish this objective, they encourage more effective use of the school day, longer school days, or a longer school year. They also recommend that students develop study skills for more effective use of time.

\section{Time Problems: Roles for Technologies}

There are very fundamental roles for technology in helping us to address these issues of time management in education. Probably the most important is rarely mentioned in any of the major reports on problems of education. Since so many of the problems with learning today involve the disconnection of formal school learning from the informal learning of everyday life, great time resources stream by, quite untapped, outside the normal school hours. Already we see software and computer companies preying on this fact, playing in their ads on the guilt of parents by urging them to give their child "an early start," one that will "last for the rest of their life." And marketing studies of thousands of companies developing learning software point to the home, not the school, as the major growth market in the years ahead. Learning at home or in other cultural institutions with computer software or interactive videodisc will come to be a much more prevalent activity. But there is currently too little attempt to integrate school learning with informal learning at home and at work, given the diversity of the resources of wisdom to be found in our cultural institutions, such as museums, libraries, art galleries, and science and technology centers. This, of course, brings into even greater relief the need to eliminate problems of inequitable access to computers. As it is, the rich and gifted are those most likely to benefit from the new learning opportunities afforded by these technologies (Anderson et al., 1983).

It has now become possible to establish close links between home learning and school learning through networks. Homework and more effective use of study time could be supported by the school, and parents could learn about the new technologies and could work with teachers to coordinate learning in different environments. As some have noted, without this link, K-Marts and computer stores will soon be determining what is sold as "educational" and guiding parents' choices about what the topics and delivery systems of informal learning should be. Companies will also soon be selling cable television home access to their own "learning" software, and will proceed with what is marketable, not necessarily what is educational.

Finally, teachers throughout the country have already begun to enjoy the benefits arising from use of time-saving computer aids to lesson-plan preparation, grading, and many of the mechanical aspects of teaching preparation. With better-designed computer systems adaptable to their specific instructional needs, they will have much more time available for instruction, they will escape much tedious drudgery, and they can work on professional development to help them continue to become more effective teachers. 


\section{Problem Area 4: Teaching}

As for problems with the teaching profession, the Commission recommends that we improve the preparation of our teachers and take a variety of actions to make teaching a more rewarding and respected profession.

\section{Problems with Teaching: Roles for Technologies}

Computer technologies have many of the same potentials for teacher training as for student learning, and teachers as well as parents could serve as effective role-models by using computer technologies for their life-long learning activities. It is well-known that many of our science and math teachers do not understand what they are required to teach, and the processes of computer-based learning for teachers themselves will need basic cognitive study.

Beyond these training needs, teachers can benefit from information technologies in many other ways. There are practical roles for teachers and educators informed about learning to participate in the software research and development process. Their input can greatly contribute to the quality of software for learning, in school and in homes, and help alleviate salary deficiencies as well. Teachers and educators could exert a powerful influence on software designers by working in teams with them and with researchers in order to encourage the development of flexible, locally adaptable learning environments which would foster enthusiasm for learning, which would continually challenge the level of knowledge and skills the student has available, and which could deal both with the wisdom we want students to acquire and with the ways in which they learn how to gain and use knowledge. Graduate schools of education should be responsive to these possibilities today by providing relevant training for their students about the types of educational computer tools appearing, and by encouraging collaborative activities with software producers. The goal is clear - new ideas about educational reform using computers must come together from the "high tech" and the grassroots levels, from educational practitioners and prototype developers, and not only from "above," as in the curriculum reform efforts in the 1960s (Jackson, 1983).

It is important to emphasize that the computer is not pushing teachers away from the profession, and for many it is the coming attraction. The indispensable role of teachers in education has become increasingly obvious as software makes its ways into schools. They are the best informed about who it is that can best profit from a given software-learning experience at a given time, and can provide the timely advice and "scaffolding" on learning that eludes even the "smartest" of the artificially intelligent computer-aided instruction systems today.

\section{CONCLUSIONS}

I have briefly reviewed the recommendations made by the Commission for Excellence in Education, and listed a number of roles that information tech- 
nologies and their sister cognitive sciences can be expected to play in the years ahead as the educational community responds to the challenges raised.

But we must close on a troublesome note. Equity problems have repercussions for every single category of these recommendations. Policy changes at all educational system levels that remove inequities in quality computer access must be undertaken now, not later. The wealthiest schools are four times more likely today to have microcomputers than the poorest schools. What will happen in the decades ahead to the rural school in Mississippi? Will its teachers miss the opportunities of learning to teach with the new technologies, or its students to learn with them? Will they attain computer literacy firsthand or only through textbooks? There are ever-widening cracks in the American dream of universal education as information technologies become a greater force in the processes of education. As responsible educators and researchers, we must see to it that the demon of unequal opportunity not leave a large share of our nation's children behind in the dust of the past.

\section{REFERENCES}

Amarel, M. 1983. Classrooms and computers as instructional settings. In Theory into Practice.

Anderson, R. E., W. W. Weich \& L. J. Harris. 1983. Computer Inequities in Opportunities for Computer Literacy. University of Minnesota. Minneapolis, MN.

Barr, A. \& E. A. Feigenbaum. Eds. 1982. The Handbook of Artificial Intelligence, Vol. II. William Kaufmann. Los Altos, CA.

Brown, J. S. 1983a. Process versus product - a perspective on tools for communal and informal electronic learning. In Education in the Electronic Age: Proceedings of a Conference Sponsored by Educational Broadcasting Corporation. WNET/Thirteen. New York. NY.

Brown, J. S. 1983b. Learning-by-doing revisited for electronic learning environments. In The Future of Electronic Learning. M. A. White, Ed. Erlbaum. Hillsdale, NJ.

Bruce, B. C., S. Michaels \& K. Watson-Gegeo. 1984. Computers and the Writing Process. Bolt, Beranek \& Newman. Cambridge, MA. Manuscript submitted for publication.

Buchanan, B. G., D. H. Smith, W. C. White, R. J. Gritter, E. A. Feigendaum, J. LEDERBERG \& C. DJeRASSI. 1976. Applications of artificial intelligence for chemical inference: XXII. Automatic rule formation in mass spectrometry by means of the Meta-DENDRAL program. J. Am. Chem. Soc. 98: 6168-6178.

Champagne, A. B. \& L. E. Klopfer. 1977. A sixty-year perspective on three issues in science education: 1. Whose ideas are dominant? II. Representation of women. III. Reflective thinking and problem solving. Sci. Ed. 61: 431-452.

Char, C., J. Hawkins, J. Wooten, K. Sheingold \& T. Roberts. 1983. Voyage of the Mimi: Classroom Case Studies of Software, Video, and Print Materials. U. S. Department of Education. Washington, DC.

Chipman, S. F., S. W. Segal \& R. Glaser, Eds. 1984. Thinking and Learning Skills: Current Research and Open Questions. Erlbaum. Hillsdale, NJ.

Clement, J. 1983. A conceptual model discussed by Galileo and used intuitively by physics students. In Gentner and Stevens (1983): 325-340.

Issue on Science Education. Daedulus (Spring 1983).

DAvis, R. B. 1982. Learning Mathematics: The Cognitive Science Approach to Mathematics Education. Croon-Helm. London. 
DiSessa, A. 1982. Unlearning Aristotelian physics: A study of knowledge-based learning. Cognitive Sci. 6: 37-75.

Freeman, C., J. Hawkins \& C. Char. 1984. Information Management Tools for Classrooms: Exploring Database Management Systems. Paper presented at the Annual Meetings of the American Educational Research Association, New Orleans, La.

Gagne, R. M. \& W. Dick. 1983. Instructional psychology. Annu. Rev. Psychol. 34: 261-295.

Gentner, D. \& A. L. Stevens. 1983. Mental Models. Erlbaum. Hillsdale, NJ.

Glaser, R. 1984. Education and thinking: The role of knowledge. Am. Psychol. 39: 93-104.

Griesemer, J. L. \& C. Butler, Eds. 1983. Education under Study: An Analysis of Recent Major Reports on Education. Northeast Regional Exchange. Chelmsford, MA.

Hawkins, J. 1983. Learning Logo Together: The Social Context. Technical Report No. 13. Center for Children and Technology, Bank Street College of Education. New York, NY.

JACKSON, P. W. 1983. The reform of science education: A cautionary tale. Daedulus 112: $143-166$.

Kelman, P., A. Bardige, J. Choate, G. Hanify, J. Richards, N. Roberts, J. W Alters \& M. K. TORNROSE. 1983. Computers in Teaching Mathematics. AddisonWesley. Reading, MA.

Lesgold, A. M. \& F. Reif. 1983. Computers in Education: Realizing the Potential (Chairmen's report of a research conference). Office of Educational Research and Improvement. Washington, DC.

Levin, J. A., M. J. Boruta \& M. T. Vasconellos. 1983. Microcomputer-based environments for writing: A writer's assistant. In Classroom Computers and Cognitive Science. A. C. Wilkinson, Ed. Academic Press. New York, NY.

Loftus, G. R. \& E. F. Loftus. 1983. Mind at Play: The Psychology of Video Games. Basic Books. New York, NY.

Lumsdaine, A. A. \& R. Glaser. Eds. 1960. Teaching Machines and Programmed Learning: A Sourcebook. National Education Association. Washington, DC.

MCCloskey, M. 1983. Naive theories of motion. In Gentner and Stevens (1983): 299-324.

National Commission on Excellence in Education. 1983. A Nation at Risk: The Imperative for Educational Reform. U. S. Department of Education. Washington, DC.

NeWEll, A. \& H. A. Simon. 1976. Computer science as empirical inquiry: Symbols and search. Communications of the Association for Computational Machinery 19: $113-126$.

Newell, A. \& H. A. Simon. 1972. Human Problem Solving. Prentice-Hall. Englewood Cliffs, $\mathrm{NJ}$.

Norman, D. N. 1980. Cognitive engineering and education. In Problem Solving and Education: Issues in Teaching and Research. D. T. Tuma \& F. Reif, Eds. Erlbaum. Hillsdale, NJ.

PeA, R. D. \& D. M. Kurland. 1984. Toward Cognitive Technologies for Writing. Final Workshop Report to the Sloan Foundation. (Also Technical Report No. 26, Center for Children and Technology, Bank Street College of Education. New York, NY).

Perkins, D. N. 1983. Educational Heaven: Promises and Perils of Instruction via Video Games. Paper presented at the Harvard Graduate School of Education Symposium entitled "Video games and human development: A research agenda for '80s."

RESNICK, L. B. 1982. A new conception of mathematics and science learning. Paper presented to the National Convocation on Precollege Education in Mathematics 
and Science, National Academy of Sciences and National Academy of Engineering, May 12-13, 1982.

RiEl, M. 1983. Education and ecstasy: Computer chronicles of students writing together. Quarterly Newsletter of the Laboratory of Comparative Human Cognition 5: $59-67$.

Rosegrant, T. 1983. Computer-based reading programs that talk. Paper presented at the Annual Meetings of the American Association for the Advancement of Science, Detroit, MI.

Segel, J. W., S. F. Chipman \& R. Glaser, Eds. 1984. Thinking and learning skills: Relating instruction to basic research. Erlbaum. Hillsdale, NJ.

Sheingold, K., J. Hawkins \& C. Char. 1984. "I'm the thinkist, you're the typist": The interaction of technology and the social life of classrooms. Journal of Social Issues. In press.

SHEINGold, K., J. H. KANE \& M. E. ENDREweIt. 1983. Microcomputer use in schools: Designing a research agenda. Harvard Educational Rev. 53: 412-432.

Simon, H. A. 1981. The Sciences of the Artificial, 2nd ed. MIT Press. Cambridge, MA.

SleEman, D. \& J. S. Brown, Eds. 1982. Intelligent Tutoring Systems. Academic Press. New York, NY.

Sternberg, R. J., Ed. 1982. Handbook of Human Intelligence. Cambridge University Press. Cambridge, England.

Stevens, A. L., R. B. Roberts, L. S. Stead, K. Forbus, C. Steinberg \& B. C. Smith. 1981. STEAMER: Advanced Computer-Aided Instruction in Propulsion Engineering. Report No. 4702. Bolt, Beranek \& Newman. Cambridge, MA.

TyleR, R. \& S. WhITE, Eds. 1979. Testing, Teaching, and Learning. Department of Education. Washington, DC.

W ARFIELD, R. W. \& G. M. White. 1983. The new interface technology: An introduction to windows and mice. Byte 8: 218-230.

White, S. 1981. The new liberal arts. In The New Liberal Arts: An Exchange of Views. J. D. Koerner, Ed. Alfred P. Sloan Foundation. New York, NY.

Williams, M., J. Hollan \& A. Stevens. 1981. An overview of STEAMER: An advanced computer-assisted instruction system for propulsion engineering. Behavior Research Methods and Instrumentation 13: 85-90.

Xerox Palo Alto Research Center, Members of Cognitive and Instructional SCIENCES. 1983. Digests of Recent Research: Cognitive Sciences and Cognitive Technologies. Xerox Corporation. Palo Alto, CA. 